\title{
Glukosa Darah dan Kelangsungan Hidup Benih Leptobarbus Hoevenii Dengan Kepadatan Berbeda Pada Sistem Resirkulasi
}

\author{
${ }^{1}$ Febi Febriana Putri, ${ }^{2}$ M. Sugihartono, dan ${ }^{2}$ Muarofah Ghofur \\ ${ }^{1}$ Alumni Program Studi Budidaya Perairan Fakultas Pertanian Universitas Batanghari \\ ${ }^{2}$ Program Studi Budidaya Perairan Fakultas Pertanian Universitas Batanghari \\ Jl. Slamet Riyadi, Broni, Jambi, 36122. Telp. +6074160103 \\ 1email korespondensi : Febbyfebriana17@gmail.com
}

\begin{abstract}
Jelawat fish (Leptobarbus hoevenii) is a fish native to Indonesia that is economically valuable but until now is decreasing its population due to the lack of cultivators who develop this commodity. For this reason, there needs to be steps so that the existence of this population is sustainable. The purpose of the study was to determine the most optimal density of common fish seeds (L. hoevenii Blkr) on maintenance with a recirculation system. This study used a Complete RandomIzed Design (RAL) with 4 treatments and 3 repeats, where the treatment is: Treatment A: Solid Spread 5 tails / L, Treatment B : Solid Spread 10 tails / L, Treatment C : Solid Spread 15 tails / L and Treatment D : Solid Spread 20 tails / L. The observed parameters are survival, blood glucose and water quality. The results showed that the average blood glucose was $56 \mathrm{mg} / \mathrm{dl}$ and the average survival of common fish was $99.62 \%$. Water quality measurement results showed temperatures ranging from $28.50-$ $29 o \mathrm{C}$, water $\mathrm{pH}$ ranged from 6.4-6.7, dissolved oxygen range 5-5.4 ppm, carbon dioxide values ranged from 2.1-5.1 ppm, ammonia ranged from 0.0011-0.0018.
\end{abstract}

Keywords: Blood Glucose. Jelawat Fish, Recirculation System and Survival rate

\begin{abstract}
Abstrak. Ikan Jelawat (Leptobarbus hoevenii) merupakan ikan asli Indonesia yang benilai ekonomis tinggi tetapi sampai saat ini makin berkurang populasinya karena sedikitnya pembudidaya yang mengembangkan komoditi ini. Untuk itu perlu ada langkah agar keberadaan populasi ini lestari. Tujuan dari penelitian ini adalah untuk menentukan kepadatan yang yang paling optimal benih ikan jelawat (L. hoevenii Blkr) pada pemeliharaan dengan sistem resirkulasi. Penelitian ini menggunakan Rancangan Acak Lengkap ( RAL ) dengan 4 perlakuan dan 3 ulangan, dimana perlakuan tersebut adalah : Perlakuan A : Padat Tebar 5 ekor/L, Perlakuan B : Padat Tebar 10 ekor/L, Perlakuan C : Padat Tebar 15 ekor/L dan Perlakuan D : Padat Tebar 20 ekor/L. Parameter yang diamati adalah kelangsungan hidup, glukosa darah dan kualitas air. Hasil penelitian menunjukkan bahwa rata-rata glukosa darah $56 \mathrm{mg} / \mathrm{dl}$ dan rata-rata kelangsungan hidup ikan jelawat sebesar 99,62\%. Hasil pengukuran kualitas air menunjukkan suhu berkisar antara $28.5^{\circ}-29^{\circ} \mathrm{C}, \mathrm{pH}$ air berkisar 6.4-6.7, kisaran oksigen terlarut 5-5.4 ppm, nilai karbondioksida berkisar 2.1-5.1 ppm, amoniak berkisar 0.0011-0.0018.
\end{abstract}

Kata kunci : Glukosa Darah, Ikan Jelawat, Kelangsungan Hidup dan Sistem Resirkulasi

\section{PENDAHULUAN}

Ikan jelawat (Leptobarbus hoeven Blkr) adalah jenis ikan asli Indonesia yang memiliki habitat hidup pada air tawar dan berpotensi untuk di kembangkan. Menurut Prasetio et al., (2016) habitat ikan jelawat mudah untuk ditemukan pada beberapa wilayah Kalimantan dan Sumatera serta digemari oleh masyarakat yang ada di wilayah Riau, Jambi, Sumatera Selatan, Kalimantan Tengah dan Kalimantan Barat.

Kegiatan pembudidayaan ikan Jelawat harus memperhatikan hal-hal yang berkaitan dengan pertumbuhan ikan Jelawat. Beberapa aspek yang berkaitan dengan pertumbuhan ikan Jelawat adalah padat tebar, pakan dan lingkungan. Hal ini sesuai pendapat Prasetio et al., (2016) yang menyatakan bahwa padat tebar yang semakin meningkat menyebabkan jumlah pakan yang diberikan juga akan bertambah, sehingga buangan metabolisme dari ikan menjadi tinggi dan menyebabkan kualitas air menurun. Hal ini menunjukkan bahwa derajat kelangsungan hidup dan pertumbuhan ikan dipenagruhi oleh padat tebar. Apabila padat tebar kurang baik, maka menyebabkan kegagalan dalam produksi.

Hasil Penelitian Rusliadi et al., (2015) menunjukkan bahwa kepadatan 30 ekor/100 liter air menunjukkan hasil terbaik dalam pemeliharaan benih ikan jelawat pada sistem resirkulasi dengan bobot mutlak sebesar 3,03 g, panjang mutlak 1,67 cm, laju pertumbuhan harian 1,99\% dan tingkat kelangsungan hidup 90\%. Akan tetapi, hasil penelitian tersebut belum menunjukkan jika padat tebar pada sistem resirkulasi memberikan pengaruh terhadap pertumbuhan ikan jelawat.

Upaya untuk menciptakan keadaan lingkungan air yang baik pada akuakultur adalah menggunakan sistem resirkulasi. Menurut Gunawan et al., (2020) penggunaan sistem resirkulasi memberikan keuntungan berupa kondisi air dalam akuarium dapat terkontrol dengan baik sehingga lebih efektif dalam pemanfaatan air.

Tujuan dari penelitian ini adalah untuk menentukan kepadatan yang yang paling optimal benih ikan jelawat $(L$. hoevenii Blkr) pada pemeliharaan dengan sistem resirkulasi. 
Febi Febriana Putri, M. Sugihartono, dan Muarofah Ghofur. Glukosa Darah dan Kelangsungan Hidup Benih Leptobarbus Hoevenii Dengan Kepadatan Berbeda Pada Sistem Resirkulasi

\section{METODOLOGI PENELITIAN}

Penelitian ini dilaksanakan pada bulan Agustus sampai dengan September 2020. Tempat penelitian di Balai Benih Ikan Daerah Telanaipura Provinsi Jambi.

Alat dan bahan yang akan digunakan dalam pelaksanaan penelitian ini adalah akuarium benih (ukuran 70x40x30 cm), pompa air ( daya $230 \mathrm{~W})$, kran air (1/2 inch), aerator (kapasitas daya $52 \mathrm{~W})$, pipa paralon (1/2 inchi), serok halus (1 unit), baskom (ukuran $50 \mathrm{~cm}$ sebanyak 2 unit), literan air (ukuran $2000 \mathrm{ml}$ ), timbangan digital (satuan gram), alat pengukur kualitas air (thermometer, $\mathrm{pH}$ meter, DO meter dan titrasi), alat tulis (buku dan pena), kamera digital (600d), penggaris $(30 \mathrm{~cm})$, botol sampel (winkler), tedmon air (1000 L sebanyak 1 unit), bak penampungan air (drum) ukuran $150 \mathrm{~L}$ sebanyak 2 unit), bak filter (ukuran 1 x 1,5 meter sebanyak 1 unit), media filter (batu zeolit, busa dan bioball) alat ukur glukosa darah (accu-check active). Bahan uji yang digunakan dalam penelitian ini adalah benih ikan Jelawat (L. Hoevenii, Blkr) sebanyak 8.400 ekor, dan pakan untuk benih ikan Jelawat (L. Hoevenii, Blkr) berupa pellet (pakan komersial).

Penelitian ini menggunakan Rancangan Acak Lengkap ( RAL ) dengan 4 perlakuan dan 3 ulangan, dimana perlakuan tersebut adalah : Perlakuan A : Padat Tebar 5 ekor/L, Perlakuan B : Padat Tebar 10 ekor/L, Perlakuan C : Padat Tebar 15 ekor/L dan Perlakuan D : Padat Tebar 20 ekor/L.

Benih ikan jelawat yang berukuran 2 inchi dengan bobot ikan sebesar 25 gram dimasukkan ke dalam akuarium dengan padat tebar masing-masing perlakuan yaitu 5, 10, 15 dan 20 ekor per liter air dengan volume air sebanyak 56 liter. Proses pemberian pakan dilakukan secara kenyang (satiation) dengan frekuensi pemberian sebanyak 3 kali sehari yaitu pagi, siang dan sore hari. Untuk pengambilan sampel ikan yang akan diukur sebanyak $10 \%$ dari jumlah populasi per akuarium. Pengambilam sampel darah untuk mengukur glukosa dara ikan dilakukan menggunakan alat accu-chek active, pada ekor ikan dan pengambilan sampel darah dilakukan pada awal dan akhir penelitian. Sedangkan untuk pengecekan kualitas air akan dilakukan sebanyak 3 kali yaitu pada awal, tengah dan akhir penelitian. Parameter kualitas air yang akan diukur meliputi suhu, $\mathrm{pH}, \mathrm{DO}, \mathrm{CO}_{2}, \mathrm{NH}_{3}$.

Parameter yang diamati adalah glukosa darah, kelangsungan hidup dan kualitas air. Data tingkat kelangsungan hidup, respon glukosa darah dianalisis menggunakan analisis sidik ragam, menggunakan software SPSS pada selang kepercayaan 95\%, analisis ini dilakukan untuk menentukan apakah perlakuan berpengaruh nyata atau tidak terhadap tingkat kepadatan tinggi benih ikan Jelawat ( L. hoevenii Blkr). Apabila berpengaruh nyata, dilakukan uji lanjut menggunakan uji Tuckey. Parameter kualitas air dianalisis secara deskriptif dan disajikan dalam bentuk tabel untuk melihat kelayakan media budidaya ikan bagi kelangsungan hidup dan pertumbuhannya.

\section{HASIL DAN PEMBAHASAN}

Berdasarkan hasil penelitian mengenai kepadatan benih ikan jelawat (L. hoevenii Blkr) pada pemeliharaan dengan sistem resirkulasi selama 50 hari, diperoleh jumlah tingkat kelangsungan hidup, panjang mutlak dan berat mutlak ikan jelawat pada masing-masing perlakuan pada Tabel 1.

Tabel 1. Hasil Uji Parameter Penelitian Ikan Jelawat dengan Padat Tebar Berbeda pada Sistem Resirkulasi

\begin{tabular}{clcccc}
\hline \multirow{2}{*}{ No } & Parameter & \multicolumn{3}{c}{ Perlakuan } \\
\cline { 3 - 6 } & & A & B & C & D \\
\hline 1 & Glukosa Darah (mg/dl) & $51,17^{\mathrm{d}}$ & $52,00^{\mathrm{c}}$ & $52,50^{\mathrm{b}}$ & $56,00^{\mathrm{a}}$ \\
\hline 2 & Kelangsungan Hidup (\%) & $98,83^{\mathrm{a}}$ & $99,33^{\mathrm{a}}$ & $99,62^{\mathrm{a}}$ & $98,61^{\mathrm{a}}$ \\
\hline
\end{tabular}

Keterangan : angka-angka yang diikuti oleh huruf yang berbeda menunjukkan perlakuan berbeda nyata pada uji Tuckey taraf 5\% $(0,05)$

\section{Glukosa Darah}

Data pada tabel di atas menunjukkan bahwa perlakuan dengan glukosa darah paling rendah adalah perlakuan A (5 ekor/l) yairu $51,17 \mathrm{mg} / \mathrm{dl}$ dan perlakuan dengan glukosa darah paling tinggi adalah perlakuan D (20 ekor/l) sebesar $56 \mathrm{mg} / \mathrm{dl}$. Hal ini menunjukkan bahwa semakin tinggi kepadatan benih ikan jelawat maka semakin tinggi pula kadar glukosa darah ikan jelawat karena ikan semakin stress. Hal ini sesuai pendapat Utami et al., (2018) bahwa semakin tinggi nilai glukosa darah melebihi diduga ikan tersebut mengalami stress. Padat penebaran yang tinggi akan menyebabkan kompetisi pada oksigen, pakan dan ruang gerak yang menyebabkan stress.

Selain itu, kepadatan tinggi menyebabkan kualitas air dalam akuarium semakin cepat menurun yang berakibat pada kondisi ikan. Menurut Royan et al., (2015) pada saat ikan mengalami gangguan yang menyebabkan stress, baik karena penanganan, kualitas air maupu infeksi bakteri, maka ttubuh ikan akan mengeluarkan tanda sebagai indikasi adanya gangguan, salah satunya adalah meingkatnya glukosa darah.

Hasil penelitian juga menunjukkan bahwa glukosa darah benih ikan jelawat dalam penelitian ini masih berada dalam kisaran normal yaitu 51,17-56 mg/dl. Hal ini sesuai dengan pendapat Rizki et al., (2020) bahwa kisaran 
glukosa darah normal ikan Jelawat adalah 50,00-60,00 mg/dl. Apabila glukosa darah benih ikan Jelawat lebih rendah maupun lebih tinggi, maka kemungkinan besar ikan mengalami setress selama pemeliharaan.

\section{Kelangsungan Hidup Ikan Jelawat (\%)}

Tabel 1. Menunjukkan bahwa kepadatan yang berbeda pada pemeliharaan benih ikan jelawat menggunakan sistem resirkulasi tidak memberikan pengaruh nyata terhadap kelangsungan hidup ikan jelawat. Rata-rata kelangsungan hidup ikan jelawat dalam penelitian ini dapat dilihat pada Gambar 1.

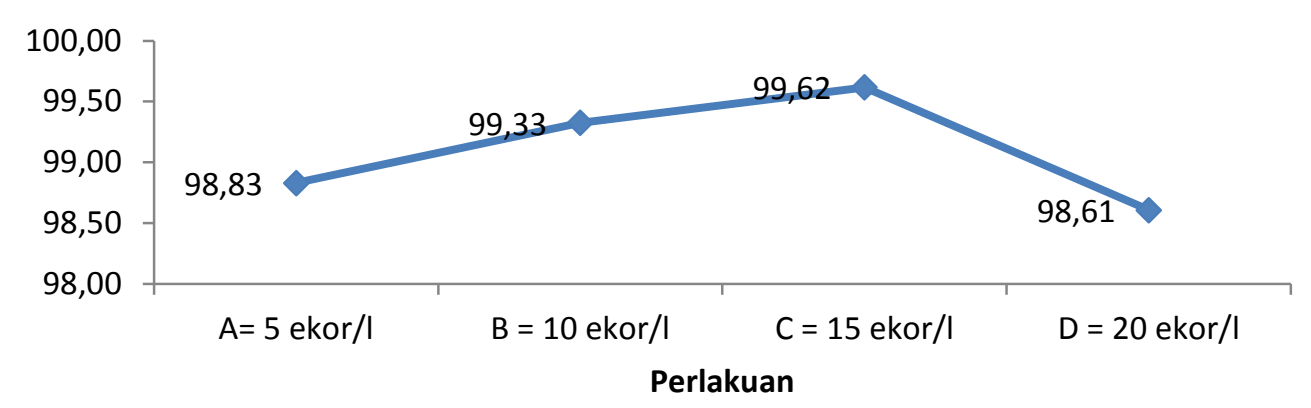

Gambar 1. Rata-Rata Kelangsungan Hidup Ikan Jelawat (\%)

Berdasarkan Gambar 1 selama 50 hari pemeliharaan, kelangsungan hidup ikan jelawat tidak menunjukkan perbedaan yang signifikan. Rata-rata kelangsungan hidup ikan jelawat sebesar 98,61\%-99,62\% dengan kelangsungan hidup paling tinggi ada di perlakuan $\mathrm{C}$ yaitu $99,62 \%$. Hasil analisis ragam menunjukkan bahwa kepadataan dalam pemeliharaan ikan jelawat dengan sistem resirkulasi belum memberikan pengaruh nyata terhadap kelangsungan hidup ikan jelawat $(\mathrm{P}>0,05)$.

Hal ini dikarenakan pemeliharaan ikan jelawat dalam penelitian ini menggunakan sistem resirkulasi sehingga kondisi air dalam akuarium dapat terjaga seperti suhu stabil, kadar oksigen terdistribusi dengan baik serta keseimbangan biologis dalam air tetap terjaga. Hal ini sesuai pendapat Jubaedah et al., (2020) bahwa adanya sistem resirkulasi dalam pemeliharaan ikan akan menyebabkan suhu perairan menjadi stabil, oksigen terdistribusikan dengan baik, kondisi biologis air terjaga dan hasil metabolisme dapat dikontrol dehingga kadar racun dalam air dapat diminimalisir.

Penggunaan filter dalam sistem resirkulasi juga ikut berperan dalam kelangsungan hidup ikan jelawat. Menurut Darmayanti et al., (2018) penggunaan filter dapat merombak sisa-sisa metabolisme akibat aktivitas ikan, ammonia dan nitrit yang dapat diubah menjadi senyawa lain yang kurang beracun melalui proses ammoniafikasi dan nitrifikasi dengan menggunakan sistem filter biologis, sehingga dapat meningkatkan tingkat kelangsungan hidup ikan yang dipelihara. Selanjutnya menurut Alfia et al., (2013) adanya filter dalam sistem resirkulasi juga dapat mengurangi akumulasi ammonia dalam media peemliharaan seiring bertambahnya ukuran ikan dan lamanya waktu pemeliharaan

Tingginya kelangsungan hidup perlakuan $\mathrm{C}$ dibanding perlakuan $\mathrm{A}$ dan $\mathrm{B}$ diduga karena ikan jelawat memiliki kebiasaan hidup secara bergerombol dan berenang melawan arus. Apabila padat tebar dalam akuarium terlalu sedikit seperti perlakuan A dan B maka ikan akan mengalami stress karena gerombolannya hanya sedikit ketika ikan-ikan ini berenang dalam sistem resirkulasi, sedangkan pada perlakuan $\mathrm{D}$ jumlah padat tebar terlalu tinggi dan mempengaruhi kualitas perairan. Hal ini sesuai pendapat Fauzi (2018) bahwa anak ikan jelawat memiliki kebiasaan hidup bergerombol dan berenang melawan arus, sehingga anak ikan jelawat akan merasa aman ketika berenang secara bergerombol.

Selanjutnya meskipun kelangsungan hidup ikan jelawat dalam penelitian ini masih cukup tinggi yaitu lebih dari 90\%, tetapi pada perlakuan D (20 ekor/l) menunjukkan hasil terendah dibanding perlakuan lain. Hal ini diduga karena kepadatan yang tinggi menyebabkan aktivitas benih ikan dalam akuarium menjadi terbatas. Hal ini sesuai pendapat Rahmawati et al., (2016) bahwa semakin tinggi kepadatan maka aktivitas ikan menjadi terbatas, sehingga untuk jenis ikan yang aktif akan sulit bergerak, serta kepadatan yang tinggi juga dapat menyebabkan pertarungan antar ikan yang berakibat pada kematian ikan itu sendiri. 
Febi Febriana Putri, M. Sugihartono, dan Muarofah Ghofur. Glukosa Darah dan Kelangsungan Hidup Benih Leptobarbus Hoevenii Dengan Kepadatan Berbeda Pada Sistem Resirkulasi

Tabel 2. Hasil Pengukuran Parameter Kualitas Air Masing-Masing Perlakuan

\begin{tabular}{|c|c|c|c|c|c|}
\hline \multirow{2}{*}{ Parameter } & \multicolumn{4}{|c|}{ Nilai Kisaran } & \multirow[b]{2}{*}{ Standar } \\
\hline & A & $\mathrm{B}$ & $\mathrm{C}$ & $\mathrm{D}$ & \\
\hline Suhu $\left({ }^{\circ} \mathrm{C}\right)$ & $28,5-29$ & $28,5-29$ & $28,5-29$ & $28,5-29$ & $25-28^{\circ} \mathrm{C}$ (Utami et al., 2018) \\
\hline $\mathrm{pH}$ & $6,4-6,7$ & $6,5-6,6$ & $6,4-6,6$ & $6,4-6,6$ & 5,5-6 Rusliadi et al., 2015) \\
\hline DO (mg/L) & $5,3-5,4$ & $5,3-5,4$ & 5,3 & $5,0-5,1$ & 3,82-5,48 ppm (Rusliadi et al., 2015) \\
\hline $\mathrm{CO} 2(\mathrm{mg} / \mathrm{L})$ & $2-4$ & $2,1-4,0$ & $2,3-4,6$ & $2,5-5,1$ & 8,6-10,73 mg/l (Rusliadi et al., 2015) \\
\hline Ammonia (mg/L) & $0,0011-0,0013$ & $0,0012-0,0014$ & $0,0013-0,0016$ & $0,0016-0,0018$ & 0,0035-1,0327 mg/l (Rusliadi et al., 2015) \\
\hline
\end{tabular}

Tabel 2. Menunjukkan hasil pengukuran kualitas air dalam penelitian ini masih berada pada kisaran normal dan memenuhi standar mutu dalam sistem resirkulasi. Suhu air pada sistem resirkulasi dari masing-masing perlakuan dalam penelitian ini berkisar $28,5-29^{\circ} \mathrm{C}$ dan masih berada pada kisaran normal. Hal ini dikarenakan rata-rata suhu air dalam sistem resirkulasi berkisar antara $25-28^{\circ} \mathrm{C}$ (Utami et al., 2018). Hal ini menunjukkan bahwa suhu dalam penelitian ini masih aman untuk pemeliharaan dan tumbuh kembang benih ikan jelawat. Menurut Puslitbangkan (1992) dalam Cahyadi et al., (2015) suhu air ikan jelawat untuk dapat tumbuh kembang dengan baik pada 29-30 ${ }^{\circ} \mathrm{C}$.

Hasil pengukuran parameter air dalam penelitian ini menunjukkan bahwa $\mathrm{pH}$ air melalui sistem resirkulasi berkisar antara 6,4-6,6. Kisaran $\mathrm{pH}$ tersebut masih normal dan sesuai standar $\mathrm{pH}$ air dalam sistem resirkulasi yaitu 5,5-6 (Rusliadi et al., 2015). Berdasarkan hal tersebut, maka air dalam sistem resirkulasi dalam penelitian ini masih aman untuk kehidupan ikan Jelawat. Menurut Rudayat (1990) dalam Cahyadi et al., (2015) ikan jelawat mempunyai ketahanan terhadap $\mathrm{pH}$ rendah (5,5-6) dan $\mathrm{pH}$ tinggi (5-7).

Selanjutnya kadar oksigen terlarut (DO) air dalam penelitian ini sebesar 5,0-5,4 mg/L, $\mathrm{CO}_{2}$ berkisar antara 2,80-3,63 mg/L dan kadar ammonia sebesar 0,0011-0,0018 mg/L. Hal ini menunjukkan bahwa kadar DO, $\mathrm{CO}_{2}$ dan ammonia dalam penelitian masih berada dalam kisaran normal dan dapat digunakan untuk pemeliharaan ikan jelawat. DO yang normal untuk hidup ikan jelawat berkisar antara 3,4-5,8 mg/L, kadar ammonia berkisar 0,008$0,015 \mathrm{mg} / \mathrm{L}$ (Riyoma et al., 2020) dan kandungan $\mathrm{CO}_{2}$ dalam air yang cocok untuk kehidupan ikan jelawat adalah $<12 \mathrm{mg} / \mathrm{L}$ (Rusliadi et al., 2015).

\section{KESIMPULAN}

Berdasarkan hasil penelitian dapat disimpulkan bahwa glukosa darah benih ikan jelawat yang dipelihara dalam sistem resirkulasi adalah $56 \mathrm{mg} / \mathrm{dl}$ dan kelangsungan hidupnya sebesar $99.62 \%$.

Perlu adanya penelitian lanjutan terhadap kepadatan pemeliharaan benih ikan Jelawat pada sistem resirkulasi dengan melihat pengaruh dari filter yang digunakan, sehingga dapat diketahui apakah terdapat hubungan antara kepadatan benih dengan penggunaan filter terhadap pertumbuhan dan kelangsungan hidup ikan jelawat.

\section{DAFTAR PUSTAKA}

Alfia, A.R., E. Arini dan T. Elfitasari. 2013. Pengaruh Kepadatan Yang Berbeda Terhadap Kelulushidupan dan Pertumbuhan Ikan Nila (Oreochromis niloticus) Pada Sistem Resirkulasi Dengan Filter Bioball. Journal of Aquaculture Management and Technology. Vol. 2 No. 3 : 86-93.

Cahyadi, R., I. Suharman dan Adelina. 2015. Utilization of Fermented Water Hyacint (Eichornia crassipes) meal in the diets on Growth of Jelawat (Leptbarbus hoeveni). Laboratory of Fish Nutirition, Faculty of Fisheries and Marine Science, University of Riau.

Darmayanti, E,I Raharjo dan Farida. 2018. Sistem Resirkulasi Menggunakan Kombinasi Filter Yang Berbeda Terhadap Pertumbuhan Benih Ikan Jelawat (Leptobarbus hoeveni Blkr). Universitas Muhammadiyah Pontianak. Jurnal Ruaya Vol. 6. No .2. Th 2018. -ISSN 2541 - 3155.

Fauzi, A.R. 2018. Uji Efektivitas Ekstrak Etanol, Daun Kembang Sepatu Sebagai Immunostimulan Ikan Jelawat yang Diinfeksi dengan Bakteri Aeromonas hydrophila. Skripsi. Fakultas Perikanan dan Ilmu Kelautan, Universitas Muhammadiyah Pontianak, Pontianak.

Gunawan, B.S., U.M. Tang dan H. Syawal. 2020. Efisiensi Penggunaan Jenis Filter Dalam Sistem Resirkulasi Terhadap Kelulusanhidupan Dan Pertumbuhan Ikan Selais (Ompok hypophthalmus). Jurnal Ruaya. Vol. 8, No. 2. ISSN: 2541-3155.

Prasetio, E., E.I. Raharjo dan Ispandi. 2016. Pengaruh Padat Tebar Terhadap Pertumbuhan Dan Kelangsungan Hidup Benih Ikan Jelawat (Leptobarbus hoeveni). Jurnal Ruaya. Vol. 4 No. 1 : 1-9. ISSN : 2541-3155.

Rahmawati, S., Hasim dan Mulis. 2016. Pengaruh Padat Tebar Berbeda Terhadap Pertumbuhan Dan Kelangsungan Hidup Benih Ikan Sidat Di Balai Benih Ikan Kota Gorontalo. Jurnal Ilmiah Perikanan dan Kelautan. Vol. 3 No. 2: 64-70.

Riyoma, A., R. Diantri dan A.A. Damai. 2020. Analisis Kesesuaian Perairan untuk Budidaya Ikan Jelawat Leptobarbus hoevenii (Bleeker, 1851) di Danau Way Jepara Kecamatan Way Jepara Kabupaten Lampung Timur. Jurnal Sains Teknologi Akuakultur. Vol 3 No 1: 19-32. ISSN : 2599-1701 
Febi Febriana Putri, M. Sugihartono, dan Muarofah Ghofur. Glukosa Darah dan Kelangsungan Hidup Benih Leptobarbus Hoevenii Dengan Kepadatan Berbeda Pada Sistem Resirkulasi

Rizki, N., M. Sugihartono dan M. Ghofur. 2020. Respon Glukosa Darah Benih Ikan Jelawat (Leptobarbus hoevenii Blkr) dalam Media Yang Diberi Ekstrak Daun Ubi Jalar (Ipomoea batatas). Jurnal Akuakultur Sungai dan Danau. Vol 5 No 2: 50-54. ISSN : 2597-8837

Royan, F., S. Rejeki dan A.H. C. Haditomo. 2015. Pengaruh Salinitas Yang Berbeda Terhadap Profil Daraah Ikan Nila (Oreochromis niloticus). Journal of Aquaculture Management and Technology. Vol 3 No. 2: 109-117.

Rusliadi., I. Putra dan Syafriyandi. 2015. Pemeliharaan Benih Ikan Jelawat (Leptobarbus hoeveni Blkr) dengan Padat Tebar Yang Berbeda Pada Sistem Resirkulasi dan Akuaponik. Berkala Perikanan Terubuk. Vol. 43. No.2 : 1-13. ISSN : 2541-3155

Utami, K.P., S. Hastuti dan R.A. Nugroho. 2018. Pengaruh Kepadatan Yang Berbeda Terhadap Efisiensi Pemanfaatan Pakan, Pertumbuhan Dan Kelulushidupan Ikan Tawes (Puntius javanicus) Pada Sistem Resirkulasi. Jurnal Sains Akuakultur Tropis. Vol. 2, No. 2 : 53-63. 